\title{
HUBUNGAN SELF MONITORING DENGAN IMPULSIVE BUYING TERHADAP PRODUK FESYEN PADA MAHASISWI RANTAU
}

\author{
Giannita Virgy Pramono ${ }^{1}$ \\ Fakultas Psikologi, Program Studi Psikologi, Universitas Kristen Satya Wacana Salatiga \\ giannita16@gmail.com \\ Doddy Hendro Wibowo ${ }^{2}$ \\ Fakultas Psikologi, Program Studi Psikologi, Universitas Kristen Satya Wacana Salatiga \\ doddy.hendro@gmail.com
}

\begin{abstract}
This study aims to reveal the relationship between self monitoring and impulsive buying on fashion products in overseas female students. The participants in this study were 259 female college students from Satya Wacana Christian University which were determined by purposive sampling technique. The instruments used in this study include (1) Self Monitoring Scale to measure self monitoring and (2) The Impulsive Buying Tendency Scale to measure impulsive buying behavior. The results of the statistical analysis show $r=0.130$ with the sig value. at $0.018(p<0.05)$ which means that there is a significant positive relationship between self monitoring and impulsive buying on SWCU overseas female students.
\end{abstract}

Keywords: female students, impulsive buying, self monitoring.

\begin{abstract}
Abstrak
Penelitian ini bertujuan untuk mengungkap hubungan antara self monitoring dengan impulsive buying terhadap produk fashion pada mahasiswi rantau. Partisipan dalam penelitian ini adalah 259 mahasiswi rantau Univeristas Kristen Satya Wacana yang di tentukan dengan teknik purposive sampling. Instrumen yang digunakan dalam penelitian ini antara lain yaitu (1) Self Monitoring Scale untuk mengukur self monitoring dan (2) The Impulsive Buying Tendency Scale untuk mengukur perilaku impulsive buying. Hasil analisis statistik menunjukkan $\mathrm{r}=0,130$ dengan nilai sig. sebesar $0,018(\mathrm{p}<0,05)$ yang berarti terdapat hubungan positif signifikan antara self monitoring dengan impulsive buying pada mahasiswi rantau UKSW.
\end{abstract}

Kata kunci: impulsive buying, mahasiswi, self monitoring. 


\section{PENDAHULUAN}

Perilaku konsumtif semakin berkembang pada zaman yang serba modern ini dan ditandai oleh adanya kehidupan mewah yang akan memberi kepuasan, kenyaman fisik, serta pola hidup konsumen. Kebutuhan konsumtif ini akan membuat konsumen cenderung membeli barang tanpa pertimbangan terlebih dahulu. Berbelanja untuk membeli suatu barang kebutuhan sehari-hari merupakan hal yang wajar untuk menunjang kehidupan atau kegiatan. Namun kegiatan berbelanja menjadi tidak wajar saat seseorang melakukan pembelian hanya untuk memenuhi keinginannya dan dilakukan secara impulsif atau tanpa perencanaan terlebih dahulu. Pembelian yang dilakukan tanpa perencanaan disebut juga impulsive buying. Fenomena impulsive buying yang terjadi pada remaja menjadi alasan penting penelitian ini dilakukan. Mahasiswa Rantau adalah sesorang individu yang melanjutkan pendidikan di luar daerah asal mereka, dengan pergi ke daerah lain untuk mencari ilmu (Kamus Besar Bahasa Indonesia, 1990). Paramita (2018) melakukan penelitian pada mahasiswa yang tinggal merantau dan tinggal terpisah dari keluarga bahwa mahasiswa yang tinggal di kos memiliki kecenderungan untuk membeli barang dan menyamakan gaya hidup untuk menyamakan diri dengan teman-teman. Rook (1987) menguraikan impulsive buying adalah sesuatu yang hedonis dan mungkin menimbulkan konflik emosional. Impulsive buying mudah hilang tergantung konsekuensi yang didapat ketika seseorang melakukan hal tersebut. Impulsive buying lebih ingin memiliki seluruh barang daripada memilik salah satu dari barang tersebut. Spontanitas yang lebih utama dibandingkan kehati-hatian untuk membeli suatu barang. Dampak negatif dari impulsive buying salah satunya yaitu sikap pemborosan, karena sebenarnya konsumen membeli barang tanpa perencanaan sebelumnya yang mengakibatkan tidak terpakainya barang tersebut. Dimensi impulsive buying Verplanken dan Herabadi (2001), membagi impulsive buying menjadi dua dimensi, yaitu kognitif yang merupakan proses psikologis seseorang yang merujuk kepada struktur dan proses mental yang meliputi pemikiran, pemahaman dan pengintepretasian, sedangkan afektif: proses psikologis dalam diri seseorang yang merujuk kepada emosi, perasaan maupun suasana hati (mood).

Self monitoring merupakan observasi dan kontrol diri yang dipicu dari lingkungan untuk memberikan perilaku sosial yang tepat, berkaitan dengan cara individu untuk meregulasi tingkah laku yang ditampilkan dalam situasi sosial dan dapat membantu individu menyesuaikan diri dalam lingkungan sosial. Self monitoring merupakan konsep yang berhubungan dengan konsep pengaturan kesan (impression management) atau konsep pengaturan diri (Snyder \& Gangestad, 1986). Dapat disimpulkan bahwa self monitoring 
merupakan kemampuan individu dalam menampilkan dirinya terhadap orang lain dengan menggunakan petunjuk-petunjuk yang ada pada dirinya maupun petunjuk-petunjuk yang ada di sekitarnya, guna mendapatkan informasi yang diperlukan untuk bertingkah laku yang sesuai dengan kondisi dan situasi yang dihadapi dalam lingkungan sosialnya (Bintang, 2016).

Berdasarkan fenomena tersebut, maka dilakukan penelitian untuk melihat bagaimana hubungan antara self monitoring dengan impulsive buying terhadap produk fesyen pada mahasiswi rantau, dengan menggunakan metode kuantitatif.

\section{METODE}

Pendekatan yang digunakan dalam penelitian ini adalah pendekatan kuantitatif. Sedangkan untuk jenis penelitian adalah jenis penelitian korelasional untuk mengetahui kekuatan dan arah hubungan yang ada diantara dua variabel yaitu self monitoring dan impulsive buying (Azwar, 2017). Populasi dalam penelitian ini adalah seluruh mahasiswi UKSW yang berasal dari daerah di luar Salatiga (merantau). Sementara sampel dalam penelitian ini ditentukan dengan teknik simple random sampling sejumlah 259 partisipan yang dikembangkan dalam Isaac dan Michael (Sugiyono, 2013).

Dalam penelitian untuk mengetahui ada atau tidaknya hubungan antara self monitoring dengan impulsive buying penulis menggunakan teknik statistik parametris korelasi product moment Pearson (Pearson Correlation) dengan bantuan SPSS.21.

Dalam penelitian ini self monitoring diukur menggunakan Self Monitoring scale yang dikembangkan oleh Snyder (1974), yang dikembangkan penulis untuk penelitian. Skala ini terdiri dari 24 aitem. Setiap komponen dalam skala self monitoring terdapat aitem-aitem yang berbentuk mendukung pernyataan atau favourable dan aitem-aitem yang berbentuk tidak mendukung atau unfavourable. Skala disusun berdasarkan komponen-komponen yaitu Expressive self control yang tediri dari 6 aitem, Social Stage Presence terdiri dari 11 aitem dan Other directed self presentatin terdiri dari 8 aitem. Sedangkan impulsive buying diukur menggunakan the impulsive buying tendency scale yang dikembangkan oleh Verplanken dan Herabadi (2001), yang dikembangkan penulis untuk penelitian. Skala impulsive buying terdiri dari 2 aspek yaitu aspek kognitif dan aspek afektif. Skala terdiri dari 10 aitem, dimana masingmasing aspek terdapat 10 aitem. Diukur dengan memakai skala Likert 1 sampai 4 dengan skala terendah 1 yang berarti responden sangat tidak sesuai dengan pernyataan yang diberikan dan skala tertinggi 4 yang berarti responden sesuai dengan pernyataan yang diberikan. Untuk memberi arti dari nilai rata-rata skor tersebut (Azwar, 2017). 


\section{HASIL DAN PEMBAHASAN}

\section{Analisis Deskriptif}

Untuk menggambarkan kondisi impulsive buying pada partisipan penelitian penulis menyusun table deskriptif yang tertuang pada tabel 1.1 berikut ini

Tabel 1.1.

Kategorisasi Skor Impulsive Buying

\begin{tabular}{llll}
\hline Kategori & Interval & $\mathrm{N}$ & Persentase (\%) \\
\hline Sangat Tinggi & $45,6 \leq \mathrm{x} \leq 56$ & 8 & 3.09 \\
Tinggi & $36 \leq \mathrm{x} \leq 45,5$ & 67 & 25.87 \\
Rendah & $24,6 \leq \mathrm{x} \leq 35$ & 144 & 55.60 \\
Sangat Rendah & $14 \leq \mathrm{x} \leq 24,5$ & 40 & 15.44 \\
\hline Jumlah & & 259 & 100 \\
\hline Mean=31,81 & & \multicolumn{2}{c}{ Standart deviasi $=7,11$} \\
\hline
\end{tabular}

Berdasarkan tabel tersebut diketahui bahwa mahasiswi Universitas Kristen Satya Wacana yang merantau secara umum memiliki skor impulsive buying yang tergolong rendah yaitu sebesar 55,60\% partisipan, tergolong tinggi sebesar 25,87\% partisipan, tergolong sangat rendah sebesar 15,44\% partisipan, dan tergolong sangat tinggi sebesar 3,09\% partisipan.

Tabel 1.2.

Kategorisasi Skor Self Monitoring

\begin{tabular}{llll}
\hline Kategori & Interval & $\mathrm{N}$ & Persentase $(\%)$ \\
\hline Sangat Tinggi & $29,26 \leq \mathrm{x} \leq 36$ & 2 & 0.78 \\
Tinggi & $22,6 \leq \mathrm{x} \leq 29,25$ & 95 & 36.82 \\
Rendah & $15,76 \leq \mathrm{x} \leq 22,5$ & 147 & 56.98 \\
Sangat Rendah & $9 \leq \mathrm{x} \leq 15,75$ & 15 & 5.81 \\
\hline Jumlah & & 259 & 100 \\
\hline Mean $=21,15$ & & Standard deviasi $=3,39$ \\
\hline
\end{tabular}

Berdasarkan tabel tersebut diketahui bahwa mahasiswi Universitas Kristen Satya Wacana yang merantau secara umum memiliki skor self monitoring yang tergolong rendah yaitu sebesar 56,98\% partisipan, tergolong tinggi sebesar 36,82\% partisipan, tergolong sangat rendah 5,81\% partisipan, dan tergolong sangat tinggi 0,78\% partisipan. 


\section{Uji Korelasi}

Untuk mengetahui ada tidaknya hubungan antara self monitoring dan impulsive buying maka dilakukan uji statistik parametrik pearson correlation. Tabel berikut ini adalah Tabel 1.5.

Uji Korelasi Pearson

\begin{tabular}{llll}
\hline Correlations & & \multicolumn{2}{l}{ Self Monitoring } \\
\hline & & \multicolumn{2}{l}{ Impulsive Buying } \\
\hline \multirow{4}{*}{ Self Monitoring } & Pearson Correlation & 1 & $.130^{*}$ \\
& Sig. (1-tailed) & & .018 \\
& $\mathrm{~N}$ & 259 & 259 \\
& Pearson Correlation & $.130^{*}$ & 1 \\
Impulsive Buying & Sig. (1-tailed) & .018 & \\
& $\mathrm{~N}$ & 259 & 259 \\
\end{tabular}

*. Correlation is significant at the 0.05 level (2-tailed).

Dari hasil uji korelasi yang dilakukan, diketahui bahwa koefisien korelasi antara variabel Self Monitoring dengan Impulsive Buying adalah sebesar $\mathrm{r}=0,130$ dengan nilai sig $=$ $0,018(\mathrm{p}<0,05)$. Sehingga dapat disimpulkan terdapat hubungan antara self monitoring dengan impulsive buying. Oleh karena itu dapat disimpulkan bahwa hipotesis dalam penelitian ini diterima.

Berdasarkan analisis statistik yang dilakukan, diketahui bahwa terdapat hubungan positif antara self monitoring dengan impulsive buying dengan $\mathrm{r}=0,130$ dengan nilai signifikan $0,018(\mathrm{p}<0,05)$. Hasil penelitian ini mendukung penelitian yang dilakukan oleh Anin, Rasimin, dan Nuryato (2008) dan Christie (2015), Destyantini (2016) dan Ahmad (2018), yang menyimpulkan bahwa terdapat hubungan positif signifikan antara self monitoring dengan impulsive buying. Sebaliknya hasil penelitian ini bertentangan dengan penelitian Miatul (2017), yang menyatakan bahwa tidak ada hubungan antara self monitoring dengan impulsive buying.

Hasil penelitian ini juga mendukung pernyataan Loudon dan Bitta (1993), mengungkapkan salah satu faktor yang memengaruhi impulsive buying adalah karakteristik konsumen seperti kepribadian, jenis kelamin, sosial demografi atau karakteristik sosial ekonomi. Diantara faktor internal yang berperan penting dalam kemunculan impulsive buying ialah self monitoring (Anin dkk., 2008; Devita, 2015). 
Adanya hubungan yang diungkap dalam penelitian ini sesuai dengan pernyataan Snyder (Baron Byrne, 1997), yang mengatakan bahwa individu yang memiliki self monitoring tinggi menunjukkan ciri-ciri tanggap terhadap tuntutan dari lingkungan sekitarnya, memerhatikan informasi sosial yang merupakan petunjuk baginya menampilkan diri sesuai dengan informasi atau petunjuk tersebut, mempunyai kontrol yang baik terhadap tingkah laku yang akan ditampilkan, mampu menggunakan kemampuan yang dimilikinya untuk berperilaku dalam situasi-situasi yang penting, dan mampu mengendalikan diri, mengubah perilaku serta ekspresif. Sebaliknya individu yang memiliki self monitoring rendah menunjukkan ciri-ciri kurang tanggap terhadap situasi-situasi yang menunjukkan ciri-ciri kurang tanggap terhadap situasi-situasi yang menuntutnya untuk menampilkan dirinya, kurang memperhatikan pendapat orang lain dan kurang memperhatikan informasi sosial, kurang dapat menjaga dan suka mengabaikan penampilannya, kurang berhasil dalam menjalin hubungan interpersonal, perilaku dan ekspresi diri lebih dipengaruhi oleh pendapat dirinya daripada situasi di sekitarnya.

Mahasiswi UKSW yang memiliki self monitoring tinggi cenderung akan menerima informasi sosial yang menjadi petunjuk baginya untuk menampilkan diri sesuai dengan informasi atau petunjuk tersebut. Sehingga apabila mahasiswi berada dalam lingkungan yang tanggap terhadap informasi mengenai gaya berpakaian seperti sepatu, baju maupun kosmetik, maka ia akan cenderung memunculkan perilaku impulsive buying pada produk-produk tersebut. Sementara itu, apabila mahasiswi memiliki self monitoring yang tinggi namun berada dalam lingkungan yang tidak tanggap mengenai gaya berpakaian maka perilaku impulsive buying dapat muncul dalam bentuk yang lain tergantung dari apa yang menjadi prioritas kelompok tersebut. Seorang mahasiswi yang terutama masih berada pada usia remaja dan memiliki tingkat self monitoring tinggi akan cenderung memiliki gaya perilaku impulsive buying yang tinggi. Hal ini bertujuan untuk menunjukkan keberadaan dirinya di dalam lingkungan tempat bergaul dan menjalin relasi sosial (Anin dkk., 2008).

Hasil penelitian ini juga mengungkapkan bahwa besaran kontribusi self monitoring terhadap impulsive buying adalah hanya sebesar 1,7\%. Sementara sisanya sebesar 98,3\% di pengaruhi oleh faktor-faktor lain yang tidak diteliti dalam penelitian ini. Sesuai dengan pernyataan Verplanken dan Herabadi (2001), bahwa terdapat faktor-faktor lain yang memengaruhi impulsive buying seperti variabel situasional (karakteristik produk, faktor marketing), dan variabel person related (emosi, konformitas, dan jenis kelamin). Pernyataan tersebut didukung oleh hasil penelitian Alfaiz (2018), yang menghasilkan temuan bahwa 
promosi, hedonic shopping dan emosi positif berpengaruh terhadap perilaku impulsive buying konsumen. Senada dengan hasil penelitian Edy dan Hatyanti (2018), mengungkapkan temuan bahwa faktor produk marketing dan konsumen itu sendiri berpengaruh terhadap impulsive buying sebesar $61 \%$.

\section{SIMPULAN}

Berdasarkan hasil penelitian yang dilakukan dapat disimpulkan bahwa terdapat hubungan antara Self Monitoring dengan Impulsive Buying terhadap produk fesyen pada mahasiswi rantau UKSW. Penulis mengajukan saran kepada beberapa pihak, yakni: bagi mahasiswi untuk lebih dapat mengelola self monitoring menjadi hal yang positif misalnya untuk mengembangkan keterampilan dan minat. Secara khusus hal ini bisa dilakukan melalui komunitas yang mendukung untuk mengembangkan minat. Dari pihak universitas dan fakultas dapat menyelenggarakan program-program yang membantu mahasiswi lebih mengembangkan kemampuan manajemen keuangan di masa depan dan diharapkan dapat memberikan pengetahuan tentang impulsive buying serta dampak dari hal tersebut. Mahasiswi juga dapat mengembangkan kemampuan pengelolaan keuangan dengan mengikuti program pelatihan investasi, enterpreneurship, maupun bentuk manajemen keuangan lainnya yang membantu mahasiswi terkait pengelolaan keuangan di masa depan. Saran bagi peneliti selanjutnya yaitu perlu dilakukan penelitian lebih lanjut mengenai Self Monitoring dengan Impulsive Buying pada sampel lain yang lebih beragam, dan dapat menyertakan variabel-variabel bebas lain selain self monitoring.

\section{DAFTAR PUSTAKA}

Alfaiz, M. D. (2018). Faktor yang mempengaruhi impulsive buying konsumen pands Yogyakarta dalam perspektif perilaku konsumsi islami (Skripsi). Fakultas Ilmu Agama Islam Univeristas Islam Indonesia, Yogyakarta.

Anin, A. F., Rasimin, B. S., \& Nuryato, A. (2008). Hubungan self monitoring dengan impulse buying terhadap produk fashion pada remaja. Jurnal Psikologi, 35(2), 181-193.

Azwar, S. (2017). Metode penelitian psikologi. Yogyakarta: Pustaka Pelajar.

Baron, R. A., \& Byrne, D. (1997). Social psychology: Understanding human interaction. Boston: Allyn and Bacon Inc. 
Bintang, P. (2016). Hubungan self monitoring mempengaruhi perilaku konsumtif pada mahasiswa psikologi Universitas Muhammadyah Surakarta (Skripsi). Fakultas Psikologi Universitas Muhammadyah Surakarta, Surakarta.

Christie, D. (2015). Pengaruh self monitoring terhadap impulsive buying pada remaja perempuan dalam pembelian produk tas replika. Parsimonia, 2(2), 43-53.

Edy, I. C., \& Haryanti, S. S. (2018). Impulsive buying behavior pada konsumen online. The National Conferences Management and Business (NCMAB). ISSN: 2621-1572.

Fuadi, A. (2018). Hubungan antara self monitoring dengan impulsive buying pada siswa SMK Taman Karya Madya Kebumen (Skripsi). Fakultas Psikologi Universitas Sarjanawiyata Tamansiswa Yogyakarta, Yogyakarta.

Humrah, M. B. S. (2017). Hubungan antara self monitoring dengan perilaku impulsive buying terhadap produk fashion pada remaja putri (Skripsi). Fakultas Psikologi Universitas Negeri Makassar, Makassar.

Sugiyono. (2013). Metode penelitian pendidikan pendekatan kuantitatif, kualitatif, dan R\&D. Bandung: Alfabeta.

Verplanken, B., \& Herabadi, A. (2001). Individual differences in impulse buying tendency: Feeling and no thinking. European Journal of Personality, 15, 71-83. 